Saudi Journal of Medicine

Abbreviated Key Title: Saudi J Med ISSN 2518-3389 (Print) |ISSN 2518-3397 (Online)

\title{
Study of the Conformity of Labeling of Alcohol-Free, Non-Carbonated Flavored Drinks Marketed In Plastic Bags in the City of Douala
}

Ngoule Charles Christian ${ }^{1}$, Bamal Hans-Denis ${ }^{1}$, Yinyang Jacques ${ }^{1}$, Etape Fabrice Edie ${ }^{1}$, Kidik Pouka Cathérine ${ }^{1}$, Ngene Jean Pierre ${ }^{1}$, Kenmogne Simo Thiery ${ }^{1}$, Dibong Siegfried Didier ${ }^{1,2^{*}}$, Claus Jacob ${ }^{3}$, Etame Loe Gisèle ${ }^{1}$

${ }^{1}$ Department of Pharmaceutical Sciences, Faculty of Medicine and Pharmaceutical Sciences, University of Douala, P.O. Box 2701 Douala, Cameroon

${ }^{2}$ Department of Plant Biology, Faculty of Science, University of Douala, P.O. Box 24157 Douala, Cameroon

${ }^{3}$ Division of Bioorganic Chemistry, School of Pharmacy, Saarland University, Campus B2 1, Raum 1.14, D-66123, Saarbrücken, Germany

DOI: $10.36348 /$ sjm.2020.v05i04.009 $\quad$ | Received: 16.04 .2020 | Accepted: 23.04 .2020 | Published: 30.04 .2020

*Corresponding author: Dibong Siegfried Didier

\section{Abstract}

Flavored drinks are substances to be prepared or ready for consumption, including syrups and those containing caffeine. Their specific denomination may be replaced by another, which is either usual or descriptive such as "refreshing drink", "table drink" or "drink made from ..." that allows consumers to know the real nature of the beverage and to distinguish it from others. The quality of these dubious products is still poorly known although in terms of cost, they remain very accessible to any Cameroonian eager to quench their thirst. This experimental study focused on the analysis of the labeling compliance of non-alcoholic and non-carbonated flavored drinks marketed in plastic bags in Douala. This was assessed using an index card based on the codex standard for the labeling of prepackaged foods. A total of 50 samples of these quality requirements defined by Codex Alimentarius standards for drinks were analyzed and the results showed a $53 \%$ non-compliance rate. This high rate of non-compliance in pre-packaged food aimed at human consumption calls for a review of sanctions and better control of drinks sold in the streets of Douala.

Keywords: Flavored drinks, Standard, Labeling.

Copyright @ 2020: This is an open-access article distributed under the terms of the Creative Commons Attribution license which permits unrestricted use, distribution, and reproduction in any medium for non-commercial use (NonCommercial, or CC-BY-NC) provided the original author and source are credited.

\section{INTRODUCTION}

Today, in developing countries in general, and particularly in Cameroon, economic liberalism is seen as a strategic option for real economic development and this context implements the development of new nonalcoholic flavored drinks, more suited to low-income populations.

Flavored drinks are that ready to drink, including syrups and drinks containing caffeine. Their specific name can be replaced by another that can be usual or descriptive, such as 'lemonade', 'refreshing drink', 'table drink' or 'drink made of...' which allows consumers to know the true nature of the beverage and distinguish it from those with which they might confuse [1].

It was shown that $75 \%$ of non-alcoholic drinks in Cameroon were consumed in the cities of Yaoundé and Douala [2]. Direct interviews and observations showed that in recent years, these products are increasingly being marketed in the streets of Douala in the form of non-alcoholic, non-carbonated, flavored drinks packaged in thermo-welded plastic bags.
However the food is a fundamental need for life, which implies that it should meet some conditions. For example, it should not be described or presented on the label or in labeling by words, images, or in any other way referring or alluding directly or indirectly to another product with which it could be confused. Furthermore, it should not be presented in a way that suggests to the purchaser or consumer that it is related to that other product [3]. The objective of this work is to study the compliance of the labelling of these drinks with an aim to promote the healthy consumption of these products and to warn consumers about the standards surrounding the quality of the information they need.

\section{MATERIAL AND METHODS Sampling}

This was an experimental study conducted from December 2017 to June 2018 in Douala, Cameroon. Samples were taken from four markets, randomly selected in the city and one supermarket with high affluence. The chosen sites were: Nkololoun, New Deido, Large Hangar, Bepanda Double-Balle and supermarket Santa Lucia. The collected samples were 
then sent to the Food, Para-pharmaceutical and Cosmetics Quality Control Laboratory of the University Institute of Technology, Douala for analysis. Sample selection was based on the description of soft drinks according to Cameroon's NC 206: 2003-02 standard and the sampling plan were based on the European Commission's guidance document $[4,5]$. In the absence of lot numbers on the vast majority of sample tags, five units were collected for each brand and for the sample collection, the markets and the supermarket were surveyed from one end to the other. A total of 50 samples were acquired for this study.

\section{Labelling Compliance Analysis}

The labelling compliance analysis was conducted using a fact sheet based on elements of
Cameroon's NC 04:2000 standard, which is identical to CODEX STAN 1-1985 [6].

\section{RESULTS AND DISCUSSION \\ Labelling compliance monitoring}

The labelling compliance analysis was represented (Figures 1, 2). Only 6\% of the labels mentioned the lot number. $10 \%$ of labels mentioned the acronym of the national brand ' $\mathrm{NC}$ ' (for Norme Camerounaise: Cameroonian Standard). A sample is declared compliant if and only if all mandatory mentions are present and defined according to the specifications of the Cameroonian standard for labelling pre-packaged foods. Only 23 out of 50 samples, or $47 \%$, are considered to be in compliance with the labelling standard, compared to $27 / 50$ deemed noncompliant, or $53 \%$ non-compliance.

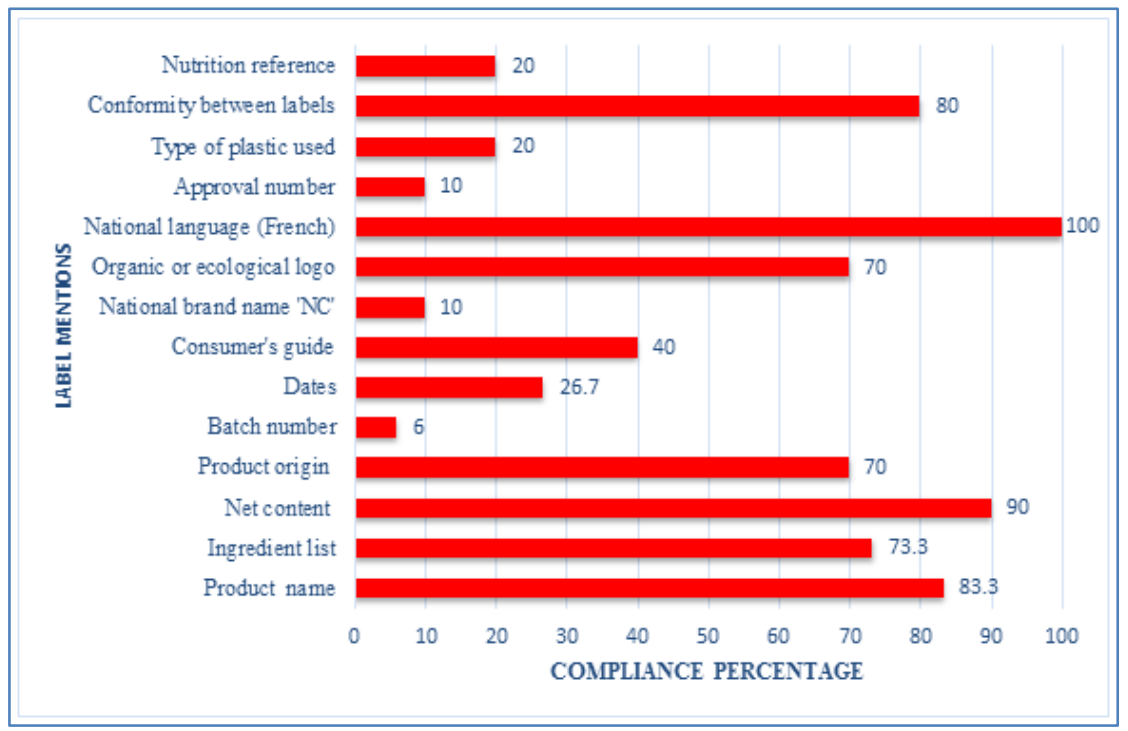

Fig-1: Compliance percentage of the samples to the standard labeling requirements

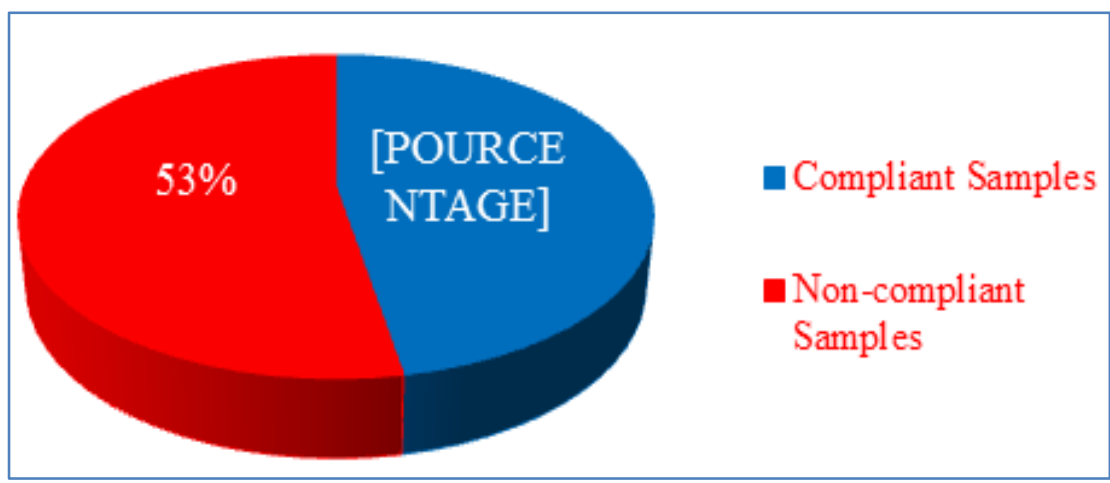

Fig-2: Samples' compliance with labelling standards. Only $47 \%$ of the sample did comply with the national standards for pre-packaged foods labelling

\section{DISCUSSION}

\section{Analysis of the conformity of the labels}

\section{Presence of mandatory information on labels}

The product's name was not mentioned on $16.7 \%$ of the samples. The absence of this precision may mislead consumers, making it nearly impossible for them to know what is being consumed. This also brings confusion due to inappropriate terms such as "fruit juice" which represents rather another category of drinks, different from flavored drinks according to CODEX STAN 192-1995 [7]. Failing to specify the true nature of the product can be interpreted as a desire to mislead the consumer. This behavior is prone to sanctions clearly defined in the regulations [8]. 
Some samples $(26.7 \%)$ did not mention a list of ingredients, as required by the standards. Within these samples, a portion had lists only mentioning the category of the additives present in the beverage, e.g. sweetener, stabilizer or dye, without indicating the specific names of the additives. Furthermore, the analysis showed samples that only made the ingredient list available on a very low and minute area of the sachet. Not specifying the list of ingredients may imply a desire to deceive the consumer's vigilance by letting them believe that the product is suitable for everyone [8].

Some of the samples $(30.0 \%)$ did not mention the manufacturer's name and address. In order to have traceability on the origin of the product and the commitment of the manufacturer or distributor of products made available to the population, the manufacturer's name, address and country of origin must be mentioned on the label [9]. Labels without a name or address from the manufacturer are likely to mislead consumers and level of dishonesty from the manufacturers.

Most samples (94.0\%) did not have a lot number. Some samples had a lot number that is poorly written, partially erased, or barely visible. Failure to mention the lot number calls into question the quality of the production line and the credibility of the manufacturer. No lot number on the package means that if there is concern about the quality of the available sample, a decision can only be made on the sample, but this sample was produced in a production plant and has sister samples that are still being distributed. The lot number is an element of traceability from which all samples of the lot can be recalled from the market for destruction and sanctions to the production plant.

The production, expiration and best-before dates were not correctly mentioned on a large proportion $(73.7 \%)$ of the samples. Among these samples, some do not have a manufacturing date, others do not have an expiration date (minimum durability) and on many others, the mentions "To be consumed before the" or "Best before the" or "To be consumed preferably before the" were not completed. Not mentioning the manufacturing date and the best before date may mislead the consumer [8]. Irregularities in this reference may reflect a failing quality assurance system, which feeds the lack of credibility that these beverages possess among consumers.

Usage instructions and safety information were absent on $40 \%$ of the samples. Those instructions are necessary for the proper use of the product, including its consumption and storage. The absence of the product may be detrimental to the consumer in the sense that, being uninformed, they are likely to store the product in ways that alter its physicochemical properties, thereby running the risk of consuming a poor quality drink that could damage their health [8].

Multiple samples $(90 \%)$ did not carry the acronym of the national mark ' $\mathrm{NC}$ ' accompanied by the number of its right of use. This gives every reason to believe that either all these drinks are not certified by the Cameroon's Standards and Quality Agency (ANOR), or the authority or legitimacy of this agency is neither recognized, nor respected or is simply ignored by the sectors' actors. Another suspicion is that ANOR is not yet certified and recognized by international certification commissions, which prevents it from instructing control over these products.

\section{Presence of optional mentions}

Although not recommended by Cameroonian standards NC 206 for some, and optional for others, some mentions were observed with significant percentages. These include the Ministry of Health's accreditation number (10\%), the type of plastic or recycling cycle $(20 \%)$ and the nutritional benchmark $(20 \%)$. Despite the low percentages, the presence of these references reflects the likely existence of regulations that govern them and need to be studied more extensively. These low percentages suggest that the producers of these drinks and the authorities in charge of health safety, industry or the environment are less involved in the control of these products and the impact they can have on consumers. It therefore seems urgent to make these optional references mandatory.

\section{Compliance with the pre-packaged food labelling standard}

Labelling should not be confusing in the minds of the buyer or consumer, particularly on the characteristics of the food, including its nature, identity, qualities, composition, quantity, durability, origin or provenance, as well as some mere aspects of the manufacturing process [10]. Framework Law 2011/012 of May $6^{\text {th }}, 2011$ on consumer protection in Cameroon in Chapter II on the Principles of Consumer Protection in Article 3 stipulates that consumers have the right to the protection of life, health, safety and the environment in the consumption of technologies, goods or services [10]. The players in this sector must therefore provide the consumer with all the information necessary for the consumer to informed decision to purchase the good, through labelling.

\section{CONCLUSION}

This study contributed to a better understanding of the labelling of non-alcoholic and non-carbonated flavored drinks marketed in plastic bags in the city of Douala, Cameroon. The experimental study was conducted on a total of fifty (50) samples, described according to the Cameroonian Standard NC 204:2000 and distributed in five vegetable extracted drinks and 45 flavored beverages. The results showed $53.0 \%$ non-compliance from the collected samples. 
This rate is due to the low percentages achieved by certain mentions such as the lot number $(6.0 \%)$, the acronym of the national brand 'NC' $(10.0 \%)$, the production, expiry or best before dates $(26.7 \%)$ and user's instructions $(40.0 \%)$. Based on the results obtained, it can be concluded that these drinks do not meet the quality requirements set out in the food standards for human consumption and it would be essential to make improvements to the standards, enforcement of sanctions and the production of better quality drinks to ensure good food safety for consumers.

\section{ACKNOWLEDGMENTS}

We thank DAAD for the fruitful scientific cooperation between the University of the Saarlandes (Germany) and the University of Douala (Cameroon).

\section{REFERENCES}

1. Département fédéral de l'intérieur (DFI). (2016). Ordonnance du DFI sur les boissons. Confédération Suisse, 94.

2. Monkam, N. (1997). Le marché des boissons de fruits au Cameroun. Yaoundé: AGRO-PME, 17.

3. Boeckel, T. P. V., Hounhouigan, J. D., \& Nout, R. (2003). Les aliments: transformation, conservation et qualité. CTA.

4. Agence des Normes et de la Qualité. (2003). Norme camerounaise NC 206: 2003-02, des boissons rafraîchissantes sans alcool: Yaoundé : Agence des normes et de la qualité, 6.

5. Commission Européenne. (2006). Document d'orientation relatif à l'échantillonnage et à l'analyse microbiologique des denrées alimentaires dans le cadre des contrôles officiels effectués en application du règlement $\mathrm{CE} \mathrm{n}{ }^{\circ} 882 / 2004$ : Europe.

6. Agence des Normes et de la Qualité. (2000). Normes Camerounaises NC 04: 2000-20, pour l'étiquetage des denrées alimentaires préemballées au Cameroun: Yaoundé: Agence des normes et de la qualité, 10.

7. Codex Stan (2016). Norme Générale Codex Pour L'étiquetage Des Denrées Alimentaires Préemballées Codex Stan, 1-1995.

8. Ministère du Commerce. (2011). Loi-cadre $\mathrm{N}^{\circ} 2011 / 012$, portant protection du consommateur au Cameroun. Yaoundé.

9. Département de l'Agriculture. (2015). Codex Alimentarius: l'étiquetage des denrées alimentaires préemballées [En ligne]. FAO; 2015. Disponible : http://www.fao.org/documents/

10. Association Française Interprofessionnelle de l'Olive. (2009). Les Bonnes Pratiques d'Etiquetage, Conditions de commercialisation des Huiles d'Olive au stade du commerce de détail. France [cité le 2 octobre 2009]. Disponible : www.afidol.org. 